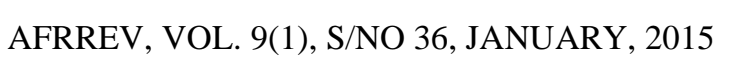 \\ 95 \\ African Research Review
}

\author{
An International Multidisciplinary Journal, Ethiopia \\ Vol. 9(1), Serial No. 36, January, 2015:95-108 \\ ISSN 1994-9057 (Print) ISSN 2070--0083 (Online) \\ DOI: http://dx.doi.org/10.4314/afrrev.v9i1.8
}

\section{The Impact of Christianity and Modernity on Ali - Earth Goddess of the Traditional Religion of the Ikwerre People, Rivers State, Nigeria}

\author{
Olumati, Rowland \\ Department of Religious and Cultural Studies, \\ Faculty of Humanities, \\ University of Port Harcourt, Nigeria
}

\begin{abstract}
This study generally focuses on Ali (Earth) deity among the Ikwerre ethnic nationality of South Eastern part of Nigeria. Ikwerre occupies four Local Government Areas in Rivers State, namely: Emohua, Ikwerre, Obio/Akpor and Port Harcourt City. The study attempts a reconstruction of the traditional heritage of beliefs and practices relating to Ali deity and examines, in the face of a rapidly changing world, where values are fast shifting with changes in Ikwerre religious beliefs and practices. Records such as books, journals, newspapers and magazines were examined. Turning to the core of the study, our research reveals that indeed, no natural phenomenon exerts so much influence and is as pervasive among the Ikwerre as Ali, the earth deity. The study shows that Ali is Ikwerre principal and arch deity and has a domineering and pervading influence on the people. Most importantly, this study negates the erroneous impression by foreign scholars, explorers, anthropologists, missionaries and ethnographers who operated in Africa that the people were not objective in handling the issue of morality. Our finding shows that in the last one hundred years or so, there have been tremendous changes on beliefs and practices relating to Ali deity. However, the story of the impact of Christianity and other agents
\end{abstract}

Copyright (C) IAARR, 2015: www.afrrevjo.net

Indexed African Journals Online: www.ajol.info 
of modern change on Ali deity in Ikwerreland is one in which at the instant of these agents of modern change, some features of the belief system elapsed while others remained resolute.

\section{Introduction}

In approaching the subject of Christianity and modern changes and its impact on Ali (Earth Goddess), it may be necessary to preface this work with a brief narrative of the beginning of Christianity in Ikwerreland in order to appreciate how this social change has affected ritual sacrifice, productivity, fertility and morality that are associated with the worship of Ali among the Ikwerre.

\section{An overview of the rise of Christianity in Ikwerreland}

There are two waves of the rise of Christian missions in Nigeria. The first began in Benin and Warri, with the Portuguese, who had arrived by sea in the fifteenth century. The Portuguese missionaries were members of various Roman Catholic orders, albeit, their efforts did not produce any lasting Church (Gbule, 2003:49). Their pre-occupation with trade and wealth, as well as their scant regard for the African indigenous culture were largely responsible for the collapse of this initial enterprise (Daudu and Gbule, 2000:8-9).

The second phase of Christian missionary activities in Nigeria started about the middle of the nineteenth century through the influence of European Christians, who were inspired by the 18th Century Evangelical Revival in Europe and America Gbule (2003). These European missionaries were members of various Protestant denominations- Baptists, Anglicans, Presbyterians, Methodists, et cetera. During this period the Christianization of Nigeria was prosecuted in three directions: the Presbyterians occupied the Efik/Ibibio axis, the Anglicans, Roman Catholics and Methodists established missions along the Niger River- Hausa land, Igbo land and the Niger Delta, whereas, Yoruba land in the west was occupied by largely, Anglicans, Baptists, and Methodists (Gbule 2003). In all these areas freed slaves, catechists, native agents, teachers, and "Bible women" led the way in the evangelization of Nigeria (2003). Each of these denominations also tried to set up rural networks by providing schooling and health facilities. Most of such facilities were later taken over by the Government on the pretext of standardizing curricula and indigenizing the teaching staff.

However, from the latter part of 20th century African indigenous Churches emerged from the mainline Churches due to disagreement over management, cultural identity and doctrines, especially those associated with prayers and charismatic gifts (Sanneh, 1989: 180). Most of these African churches were founded by small groups breaking off from the European denominations, especially in Yorubaland and the Niger Delta, where such independence movements started as early as the late 
nineteenth century. They were for the most part ritually and doctrinally identical to the parent Churches, although more African music, and later dance, entered and mixed with the imported Church services. A number also used biblical references to support polygamy. With political independence came African priests in both Roman Catholic and Protestant denominations, although ritual and forms of worship were strictly those of the European missionaries. By the 1980s, however, African songs, music and even dancing were being introduced quietly into church services, albeit altered to fit into rituals of European origin.

The "Aladura" Churches, like several other breakaway churches, stress healing and fulfilment of life goals for oneself and one's family. African beliefs that sorcery and witchcraft are malevolent forces against which protection is required are accepted; rituals are warm and emotional, stressing personal involvement and acceptance of spirit possession. Theology is biblical, but some sects add costumed processions and some accept polygamy. This trend has continued ever since with variegated forms (Hackett 2001:155). Some of these breakaway Churches or African Indigenous Churches blend traditional religious symbols with Christian symbols.

Later the Pentecostals emerged and emphasized the influence of gift of tongues, prayer, faith healing and the Holy Spirit as a norm for moral ethos, doctrine and leadership. Ogbu Kalu (2008) has accused them of forging their doctrine and ethics from the interior of African worldview.

\section{The establishment of Christianity in Ikwerreland}

It is uncertain when Christianity began in Ikwerre land (Gbule 2011). However, the Christian message was introduced into Bonny in the eastern Niger Delta in 1865 by Bishop Samuel Ajayi Crowther of the C.M.S. And from Bonny Christianity spread to other Niger Delta city-states of Nembe in 1868, Elem Kalabari in 1874, and Okrika in 1880 (Epelle 1955, Ajayi 1965).

Gbule (2011) in his Church historiography of Ikwerreland has succinctly argued that geography and ecology were a decisive factor in the Christianization of Ikwerre land. He asserts that those Ikwerre communities close to the coastal towns of Bonny, Kalabari and Okirika received the Christian message from the conversion experiences of itinerant fishermen and traders. Other parts of Ikwerre, especially those located in the hinterlands received Christianity as a result of the internal divisions within other Protestant denominations such as the Baptist Church and the United Native African Church. This according to Ndidi Gbule (2011) is the problem of ascertaining the historicity of the first Church in Ikwerre land. Among the Ikwerre communities that received the Christian message well were Isiokpo, Ndele Ibaa, Ogbakiri, Elikohia, Oginiba. Woji, Rumukrushe, Elelenwo and Rumuomasi. In all these places, the people received the new faith because of its "civilizing influences" 
of school and health facilities. For example, in 1920 there were 33 Anglican mission stations in Ikwerre land and the number of converts stood at 1,383(Epelle, 1955:72). But today the number of Anglican Churches in Ikwerre land is more than 90 (Onu,B. 2005). However, one remarkable feature of Christianity in Ikwerre land is the role played by indigenous agents and 'Bible women' in the transmission and transformation of Christian message in their various communities. This perhaps explains why the people are predominantly Anglican. In 1981 Rt. Rev Samuel Onyeuhwu Elenwo was consecrated Bishop of the Niger Delta Diocese, thus becoming the first Ikwerre Bishop (Wotogbe-Weneka, 2000). Following the creation of Ikwerre and Evo Dioceses in 2004 and 2009 respectively, two Ikwerre sons Rt. Rev Blessing Enyindah ( Ikwerre) and Rt. Rev Innocent U. Orlu ( Evo) were made Bishops. Their elevation to the bishopric met the C. M. S paradigm for the "euthanasia of missions" or the principle of "Three-Selves"- Self government, Self support, and self propagation as advocated by Henry Venn (Shenk, 1988).

\section{Traditional religious beliefs and practices of Ikwerre}

We have earlier noted that religion is an important aspect of Ikwerre cosmology. The Ikwerre religious world is complex and plural. Religion regulates their whole life and provides them with the survival kit to meet the existential needs of life. Ikwerre thought world is saturated with myriads of spirit beings (renwu) that are either benevolent or malevolent. There is no dichotomy between the material visible world and the invisible spiritual world, both flow together. Thus among the Ikwerre it is believed that various diseases, miseries, misfortunes or deaths are causally the effect of the evil spirits or supernatural forces. These spirits are so powerful that they may exert great influence on man both in his earthly life and hereafter. Just as E. B Idowu (1965) observes about the Yoruba, the Ikwerre are" in all things religious". Ikwerre religion is premised on the world view that there is the Supreme Being, known as "Chiokike", the Creator God. Chiokike is also the sustainer of the universe, which is believed to have had a clear beginning but no end. Essentially a spirit, there are no visible representations of Chiokike, and all the other beings in the ontological structure are contingent on him. He is neither a "loan" God, nor a being introduced by the missionaries as held by some Western notions (Aderibigbe, 1992:148).

Next to the Supreme Being "Chiokike", are the divinities (renwu). The divinities and spirits ("renwu") are creations of the Supreme Being ("Chiokike") for the good order of the universe. They exert influence or control over human beings, and the interaction between spirit and matter and between spiritual beings and human beings is therefore accepted as falling within the range of human experience. This helps human beings to derive meaning in life, enabling them to meet such problems as isolation, tragedy and death. The Ali, the earth goddess is the arch-divinity of 
Ikwerre and is adored as the 'mother earth'. Ali is the basic matrix of existence (Wigwe ,1989:34) and 'fons et erigo' or fountain and origin of the peoples' morality, social cohesion and fertility (Chubb1961:129; Wotogbe-Weneka 1990:143-146). Actions that are taboo to Ali include homicide, incest, suicide, stealing, sex in the bush, et cetera. They constitute a pollution of the land (Ali); and require an elaborate placatory rites by nye-kwali (the Chief priest of Ali) in order to restore the ritual purity of the Community. George Tasie emphasizes the awe the people hold for Ali when he remarks: "The belief and fear of "Eli" among Ikwerre is so pervasive that the implications and consequence of profaning it is not contemplated as the purificatory rites for offences against "Eli" are not only complex but elaborate" (2001:57).

In cases of abomination against the $A l i$, it has to be sanctified, placated and purified of the sacrilege (okwa ali) by special rituals through the office of the appropriate priest (nye risi ali) using appropriate cult objects (tortoise, fowl, kola nuts. alligator pepper, native gin or ekemeru) as advised by the oracle. The sacred day of Ali is nkwo-ihieri in Ikwerre ritual calendar. On this day, people are forbidden from farm work. Ali is so revered that children born on the sacred day are called Wali meaning literally "the son of Ali". The myth, rituals, taboos, beliefs, sanctions and emotional commitment that this worship engenders on the Ikwerre becomes an instrument of social, political and economic control. The priest of Ali for example is subject to many taboos. Thus they are forbidden as a rule to eat in another house, to eat food cooked by a woman in menstruation, or to sit or have sexual intercourse on the ground. In some communities, widows and tattooed persons are forbidden to enter the house of the priest of Ali.

Beside the cult of Ali, there is the cult of the ancestors, known as "rukani". The ancestors were once living, but when they died, they transited to the underworld, and continued to attract veneration from the living. The other component of Ikwerre ontology is the guild of religious specialists. These include the traditional herbalists, rain-doctors, diviners, sorcerers, et cetera. Thus aspects of Ikwerre religiosity can be found in their beliefs, ceremonies, rituals, arts and symbols, and religious specialists. In fact, every of their activity is rooted in religion. It is this deep-rootedness in religion that Wotogbe-Weneka has in mind when he avers: "....every Ikwerre man...at the core of his being thinks traditional, behaves traditional, and lives traditional" (1990:59-60). In a word the Ikwerre like other Africans are "notoriously" religious (Idowu, 1962:5)

\section{The impact of Christianity and social change on Ali}

Before the inception of Christianity in Ikwerre land the traditional Ikwerre society had a unitary character, especially in things related to their indigenous religions. The things of religion were never separable from things of daily life, ceremonies, birth, marriage and death (Hastings, 1977). However, Ikwerre as in other 
African societies are experiencing a violent and far reaching process of social change engendered by modernity, communication and globalization. The structures of the old society are being changed in such a way that there is an enlargement of social relationships. The Ikwerre people are no longer tied down to self-sufficient and homogenous communities. With Christianity, modernity, and globalization the Ikwerre people have had to broaden their horizon to accommodate new values and attitudinal changes. Thus the Ikwerre society is no longer unitary and homogenous but pluralistic (Kisembo, 1977:188. The people geography of the universe has been modified to emphasize mutuality, accommodation and balance. This can be discerned in power relations, gender relations, and power utilization among the adherents of Ikwerre religion, notably in the worship of $A l i$, the Earth goddess.

\section{1) Moral and social impact}

The Ikwerre people had a body of moral precepts (omenu-ali) or taboos (nsoali), which was held in high esteem before the coming of Christianity. Actions such as homicide, suicide, sex on the ground, cutting the upper teeth first, death resulting from swollen stomach, or falling from a height were regarded as sacrilege against the Earth goddess $(A l i)$. This is because among the Ikwerre Ali is the guardian of the peoples' morality and the sustainer of social cohesion and solidarity (WotogbeWeneka,W.O, 1996). In fact, E.B Idowu's (1962:146) observation of the relationship between religion and morality among the Yoruba also applies to Ikwerre. He asserts: "With the Yoruba, morality is certainly the fruit of religion. They do not make any attempt to separate the two; and it is impossible to do so without disastrous consequences". Of the relationship between morality and religion, Shorter (1973:62) argues that in African societies "morality is intimately related with the ontological order, and any infraction of this order is a contradiction of life itself, and brings disaster". Thus in Ikwerre traditional society the fear of Ali, the Erath goddess helped to reduce social crimes and acts of indiscipline to the barest minimum. There were moral laws regulating social attitudes, the etiquettes, and the laws of succession and inheritance and blood relationship. Covenant relationships between God and man, and between individuals were carefully observed. Those who broke the laws were severely punished as criminals (nye araru-ali), meaning literally someone who has desecrated the earth. This helped to maintain law and order in the traditional Ikwerre society in the absence of any regular police force (Ahirika, 2001:144).

But the problem with moral laws in Ikwerre traditional society was not its knowledge, but the ability to fulfill the law. Hence Apostle lamented thus: "I do not do what I want: But I do the very thing I hate... I will do what is right, but I cannot do it" (Romans 7:15-18).

What Christianity did to Ikwerre moral corpus was to proclaim the power of the Holy Spirit for the fulfillment of the law and righteous actions (Iwuagwu, 1996:120). By 
so doing the Church has positively reinforced the moral precepts of Ikwerre communities. The constant repetition of such teaching has contributed to check antisocial behavior in the communities. The fear of God and the eternal punishment, which are at the core of the Christian message, have helped to stabilize the Ikwerre society in a period of rapid social change. This is an aspect of mutuality, accommodation and balance with Ikwerre indigenous religion.

However, the introduction of Christianity into Ikwerre land has undermined the peoples' social and moral fabric. Hitherto, the Ikwerre people had their own religion and social order. Their religion was all-encompassing and life-fulfilling. Ali the Earth goddess was held in awe and even much more feared than Chiokike, the Supreme Being or the Creator God. This was because Ali was the palladium of the peoples' faith, morality, and social cohesion. Ikwerre people therefore took measures to observe and do all the norms, values, rituals and taboos associated with the worship of Ali. This promoted social cohesion and solidarity of the Ikwerre traditional society. But nowadays most votaries of Ali have converted to Christianity and those who did not consider it unfashionable to worship or to observe some of the ritual taboos of Ali. Tasie and Obe (2007) have observed that the Ikwerre people, who inhabit the frontiers of the Niger Delta have had their tribal religion and unity eroded due to the revolutionary ethic of Christianity. While some Ikwerre people still uphold the sanctity of Ali cult, their kith and kin, who have converted to Christianity, deride them as fetish, pagan, unbelievers, and idolaters. Thus when the issues relating to Ali and ancestral cult are mentioned, the Christian converts among them refuse to participate. This has weakened the family and social ties of Ikwerre indigenous society.

Christianity has also affected the moral life of Ikwerre people. Before now the Ikwerre people had a strong fear for Ali as the custodian of morality. This fear was borne out of the fact that Ali readily meted out punishment to offender. In the traditional Ikwerre society it was not necessarily the rebuke one received from elders that was the most restraining on anti-social behaviors but rather the fear of deities like Ali that was (Tasie 2000). It was the fear that one might die bad death either with swollen stomach or face down and thus render one unfit for life as an ancestor that was responsible for moral standard in Ikwerre. But the rise of Christianity and the apparent decline in Indigenous Religions, there is huge slide in morals. Idowu (1962) has accused Christianity of complicity for the detrimental changes in moral values of most African societies. He blames Christianity of supplanting the old fear of such divinities as Ali with the notion of a benevolent God who is ready to forgive, perhaps more than man is prone to sin. Similarly, Ayandele (1966) has blamed Christianity for the confusion of moral values in Africa. He contends that Christian missionaries did not preach a new religion but a revolutionary social ethics that life was separated into the spiritual and secular. They also required of their converts the acceptance of 
the European value system. Thus to the individualism of the Christian Religion was added the individual of a materialistic industrial West. The emphasis on individualism and the belief that life was compartmentalized into spheres of activities were diametrically opposed to the traditional African (Ikwerre) society where group and not the individual was what mattered most. Because of this, Christianity has disrupted the very social and moral foundation of African (Ikwerre) society.

\section{2) Death and burial rites}

Another aspect Ali Cult that Christianity has weakened is related to the funeral rite for the dead. It should be noted that in Ikwerre, burial ceremonies for the deceased were usually long and profound, especially those related to the aged and title holders, and religious specialists. There are rituals of "calling ghost home" ("owhekwuhia -enine"'), cleaning the corpse, embalming, wake-keeping, firing of canon shots to herald the deceased transition, lying in state, carrying of "nkpakankpa", for titled men, shaving of hairs, and the rite of "ori-elu- ojo" by widows and then interment. Such elaborate ceremonies were indicative of the importance African most societies attach to burial rites (Shorter 1993:122). But the Church considers such burial rituals as ignoble, fetish, pagan, and not contiguous with Christianity. The Churches now insist that the burial of the deceased converts must be done within two weeks; otherwise the deceased would not be accorded full Christian burial. The Church has also replaced religious wakes for the dead with an hour Service of Songs and Commendation Service before interment. This is to say the least a copy model of funeral ceremonies of the materialist and individualist West. In Africa, burial ceremonies are sacred and highly emotional, not irrational. It is also 'communitarian'. The whole community is involved (Shorter 2000:122). Sympathizers and relatives play active roles in the burial of the deceased. It afforded the people an occasion to share their grief with the deceased family. Beyond that, the burial rites go to show the strong notion the people attach to the sanctity of life and social upheaval created by death. But the Church has banned the religious observances because it considers them ignoble pagan orgies and contrary to Christianity.

The Church has denigrated burial rites for not discriminating those who died good death from bad death. In Ikwerre traditional society not all deaths are good and ipso facto do not deserve decent burial. For example, people who died by drowning, falling from a height, or on sacred days of Ali, or from a mysterious sicknesses, such as AIDS, or with the belly swollen, or died facing down ('okpu-ihni-neli') are deemed to have died a bad death resulting from undisclosed sin against Ali, the Earth Goddess. Such people are thrown into the evil forest ('ejo -ohia'). This practice ensured that the entire community retained the ritual status it enjoyed before the demise of the person. To do otherwise was to attract the wrath of the earth goddess 
("Ali"), and to render the community ritually unclean. But the Church and its leadership have continued to denigrate and undervalue these religious observances by insisting that this category of the dead should be buried at home. This has created a cultural dilemma for the indigenous Ikwerre (Tasie,G.I.K, 1999). The problem was why would persons who died bad death be buried at home by the Church knowing that the infraction of these age-long sacred observances are likely to bring disaster to the living members and the whole community?

The Churches in Ikwerre land have also prohibited the second burial rites (omesa ewhu), which was expected to hold not later than a year after the demise of the deceased. Sometimes, the second burial rites were more expensive and elaborate. Usually, it involved the polishing of the grave with red earth by the daughters of the lineage, ("rumurinya"), slaughtering of a goat ("ewu onuzuroro"), the removal of sackcloth and the shaving of the head. In Ikwerre indigenous religion and worldviews, the second burial rites were intended to help the deceased secure a permanent home in the ancestral world (Awolalu \&Dopamu, 1979:258). Defiance of the second burial, it was believed, would make the deceased roam about in the spirit world from where he would afflict and punish the living descendants with disaster and strange sicknesses (Erivwo 1991:158).

The other aspect of the disregard for traditional burial rites is related to the ancestors) ("rukani") and the spirit of the dead. The ancestors were the departed dear ones or the "living dead" (Mbiti 1977:83). They served as the link between the living and the dead. In most Ikwerre communities, beliefs and practices associated with the ancestors are very strong. This accounts for the post funeral rites which extend over a period of several years. The ancestors attract libation and receive offerings such as kola-nuts, foods, and drinks. The worldview is sustained because to the indigenous societies in Africa, one's circumstances in this life are causally influenced by the spirit world. For instance, health problems, crop failures, and personal problems are frequently attributed to the failure of the descendants to properly care for their ancestors. Sacrificial rituals are often a means to appease irate ancestors, or to make them go to sleep and leave their descendants in peace (Mullins 1998:43). But the Church insisted that for the people to be converted, the cult of the ancestor must be destroyed and replaced with the veneration of Christian Saints, who do not have any significance to the Ikwerre people. This insistence was worsened by the gospel they preached which implied that there was no hope for those who died without Christ. The exclusivist dogma was rooted in the Protestant conviction that salvation is found in Christ alone (Hodgson 1994:102). Some Ikwerre converts who straddle between the belief in the cult of the ancestors, Ali and Christianity have either chosen to practice their faith in secret or repress them (Nuremberger, 2007). What the Church in Ikwerre land failed to appreciate is that beliefs in ancestors, Ali and the spirit world 
engage and re-interpret Christianity quite differently from the Churches in Europe and America.

\section{3) Destruction of traditional religious symbols}

One of the greatest disruptions of Christianity of indigenous religious culture is in the destruction of images related to worship of divinities, especially Ali the Earth goddess. Tasie (2006) has noted that African Traditional Religion is in sacred symbols and iconography like carvings, paintings, and images, which serve as foci of mediation during ritual and worship. These religious symbols embody on the adherents the "unquestionable truth" about the cosmos and the place of man in it. Sadly, these emblems of indigenous religions have come under serious assault from Christian converts. G.O.M Tasie (1978) acknowledges this when he affirms that African religion is a practical issue, cultic and ritualistic and not an intellectual affirmation... the destruction of shrines and other traditional objects of worship displaces and dislocates the pagan priests and the symbols of traditional religion". However the early converts to Christianity in Ikwerre land were advised to destroy their objects of indigenous religion as a show of their zeal and commitment to the new religion- Christianity.

Perhaps, more devastating is the fact that all over Africa, shrines with all their paraphernalia are being destroyed by Christian missionaries. Missionary evangelism has led to the depletion of the local deities and the cults that once supported them. The discourse of religious change In Africa is studded with "the twilight of the gods them" (Barne 1980:4). The classical deities and the cults that once supported them are being replaced by the high gods of Christianity and Islam in one of the most pervasive transformations of our time. This is what Robin Horton has called 'open predicament', models for configuring closed systems into open ones. It is clear that the so-called closed systems are not closed inflexibly.

On the contrary, as indigenous societies changed, so did Christianity. The emergence of African indigenous Churches and Pentecostalism has shown the mutuality, accommodation and balance of Ikwerre indigenous religion. Many of these African Churches now prescribe forms of rituals similar to those of traditional religion in the prediction, explanation and control of time space events. Spirit possessions, divination, trance, healing features of African Indigenous religion are also present in these Churches, thus raising questions about issues of authenticity. This is what Elechi Amadi has in mind when he avers; "most spiritual Churches have prophets and apostles, who are reputed to have the powers of traditional medicine men". The African Churches interpret the gospel in terms of traditional theology and mix indigenous elements with Christian practices. In their practices some still uphold indigenous world view of evil spirits, witches and wizards to determine bad destiny and take appropriate cultic measures to remedy it. This is why Ogbu Kalu has 
asserted that African Pentecostalism derive and source their idiom from interior of African world view. For example, the symbolic use and significance of water, sand, oil, salt, palm fronds, leaves, feathers, kaolin (native white chalk), and other ritual objects is commonplace in Ali (the Earth goddess) ritual system, the context under which the Churches exist. By locating these religious objects within the precinct of the host, religious and cultural substrate, some features suggestive of affinity and discontinuity in both worldviews become manifestly clear. For many religious groups, water ("mini") is an ancient symbol of "life" and "power". The Churches use holy and sanctified water to perform both therapeutic and prophylactic functions after sanctification.

Another important ritual symbol used by African Churches and Pentecostals in its healing ministry is sand. The sand here is understood not in its biological sense but it symbolizes the source and ground of all humanity true existence. It is everywhere, and on it everybody moves. From the earth also comes food for all creatures and to the earth will creatures return at the end of earthly existence. Thus, the earth symbolizes power and real existence or one's roots. In Ikwerre cosmology, the Earth goddess ("Ali") is the guardian of morality and any moral infraction (" $n s o$ Ali") against it is visited with sickness or even death.

The point being made here is that the symbolic use of water, sand, oil and other ritual objects by the Churches for purposes of healing and spiritual empowerment has shown that the belief and worship of Ali is alive and well. The affinity and continuity of features or elements from the indigenous Ikwerre religious culture in the healing praxis of African Indigenous Churches cannot be overemphasized. There is no doubt that as the indigenous Ikwerre begins to see elements of continuities of Ikwerre ritual cosmos in Christianity; it will impact significantly upon the inner meaning of his faith and cultural identity.

\section{Conclusion}

Modernity in the form of Christianity has brought in a new form of culture. Ikwerre Christians no longer participate in worship and practices related to Ali cult since they are considered to be "primitive", "heathen", "fetish" and belonging to an uncultured way of life. They are now demonized as practices that have to be exorcised by Jesus power and the Holy Spirit. Hence an intrusive religion like Christianity with a revolutionary ethic has become the guiding principle of the present generation of Ikwerre youth. The people are in danger of losing their own identity and Ikwerre people with a distinct culture. And no society can accept changes uncritically without committing cultural suicide (Nduka, 1977). Even though the people are on the verge of facing serious identity crisis in course of time due to Christianity and globalization, there is the possibility for maintaining their age old 
cultural identity as witnessed in among the new religious movements that source, derive, and mine their idiom from the interior of African world view (Kalu 2008).

\section{References}

Aderibigbe, I. S. (2001). The Yoruba Christian and the dilemma of cultural identity: A view point. In E.A Odumuyiwa (Ed.) Religion, science, and culture. Ikenne: J. Olatunji Printers.

Adiele, S. N. (1996). The Niger mission: origin, growth and impact, 1857-1995. Aba: Isaeco Press.

Ajayi, J. F. A (1965). Christian missions in Nigeria, 1841-1891: The making of a new elite. London: Longman.

Amadi, E. (1982). Ethics in Nigerian culture. Ibadan: Heinemann.

Awolalu, J. O. \& Dopamu, P. A. (1979). West African traditional religion. Ibadan: Onibonje Press

Barne, S. T. (1980). Ogun: An old god for a new age. Philadelphia: Institute for the Study of Human Issues.

Basden, G. T. (1966). (First ed. 1938) Niger Igbos, London: Frank Cass

Chubb L. T. (1961). Ibo land tenure. Ibadan: University Press.

Daudu, M. \& Gbule, N. J. (2000). An outline of the History of Christianity in West Africa. Zaria: Mission Press.

Epelle, E. M. T. (1955). The Church in the Niger Delta. Port Harcourt: C.M.S Press.

Gbule, N.J (1982). Oha: An Institution in Obelle in Ikwerre/Etche L.G.A of Rivers State, Nigeria. Unpublished N.C.E Long Essay. Rivers State College of Education Port Harcourt.

(2003). One Hundred Years of Anglicanism in Uvuawhu Clan, 1901-2001”. Unpublished M.A Thesis. University of Port Harcourt.

(2011). Contextualization of Christianity in Anglican in Churches in Ikwerreland, 1895 2009. Unpublished Ph.D. Dissertation, University of Port Harcourt.

Hodgson, P. C. (1994). Winds of the spirit: A constructive Christian theology. London: S.C.M. Press.

Horton, R. (1971). African conversion. Journal of the International African Institute. Vol. 41 pp 85-108

Idowu, E. B. (1965). Towards an indigenous church. Ibadan: Oluseyi Press. 
(1973). African traditional religion: A definition. London: S.C.M. Press.

(1993). Olodumare: god in Yoruba belief. (Enlarged and Revised Edition) London: Longman.

Ifemesia, C., (1981). Traditional humane living among the Igbo: An historical Perspective. London: Longman.

Ikenga-Metuh, E. \& Ejizu, C. I. (1985). Hundred years of Catholicism in_Eastern Nigeria, 1885-1985: The Nnewi story. Nimo: Asele Institute.

Ilogu, E. (1974). Christianity and Igbo culture. New York: Nok Publishers

Iwuagwu, A.O. The Contributions of Anglican Communion towards the Spiritual Upliftment of the People. In S.N Adiele (ed.) The Niger mission: Origin, growth, and impact.

Kalu, O.U (1980). The history of Christianity in West Africa. Longman: Essex. (2007). African Christianity African story. New Jersey: African World Press. (2008). African Pentecostalism: An introduction. New York: O.U.P.

Mbiti. J. S. (1969). African religions and philosophy. London: Heinemann.

_ (1977). Introduction to African Religion. London: Heinemann.

Metuh, I. \& Ejizu, C. I. (1985). Hundred years of Catholicism in Eastern Nigeria; 1985: The Nnewi story. Nime: Asele Institute.

Nduka, O. (1975). Western Education and the Nigerian Cultural Background. Ibadan: O.U.P

Nuremberger, K. (2007). The living dead and the living God: Christ and the ancestors in a changing Africa. Pietermaritzburg: Cluster Publications.

Olumati, R. (2012) Elements of African Cosmology, A Traditional Legacy of Ikwerre people of Rivers State Nigeria (EPHA). Ekpoma Journal of Rel Studies Vol. 9, No. $1 \& 2$ pp. 77-96.

Olumati, R. (2011). Libation as symbolic prayers among the Ikwerre of Nigeria. Journal of Religion and Culture vol. 11, no. 1 \& 2, pp. 182-200.

Olumati, R. (2010). The symbolism of Ali Deity and its Ritual Forms in Ikwerre of Rivers State, Nig. Ekpoma Journal of Religious Studies (EPHA) Vol. 9, Nos. $1 \&$ 2, ISSN: 07 95-2988 p. 177-195.

Shenk, W. R. (1983). Henry Venn: Missionary satesman. New York: Orbis Books. 
Shorter, A. (1973). African culture and the Christian church. London: Geoffrey Chapman

Talbort, A. (1967). Tribes of the Niger Delta: Their and customs. London: Frank Cas

Tasie, G. I. K. (2001). The concept of death and after life in Isiokpo: An Ikwerre community. In C. I. Amini-Philips (ed) Historical and Cultural Perspectives of Rivers State

--- (2001). Spirit beings and morality in indigenous African religion" in W.O. Wotogbe, Weneka W. O. (ed.) Religious and spirituality. Choba, Port Harcourt: EMHAI Press.

--- (2008) Socio-historical review of early missionary enterprise and social change in West Africa. In Ilega, D. \& N. Iheanacho (eds.) Christianity in Nigeria: Advent, variety and trend. Port Harcourt: Stepson Press.

Tasie, G. O. M. (1980). Christian Awakening in West Africa 1914-1918: A Study of the Significance of Native Agency. In Kalu, O. U. (ed.) History of Christianity in West Africa. London: Longman. Pp.293-308

--- (1978). The Church in the Niger Delta. In Kalu, O.U. (ed.) Christianity in West Africa: Nigerian story. Ibadan: Onibonje Press.

Wigwe, G. A. (1986). Igbo land ownership, alienation and utilization: Studies in land as a source. In Igbo jurisprudence: Law and order.

Wotogbe, Weneka W. O. (1988), Crime and its control in the traditional religion of the Ikwerre religious periscope. A Journal of Religious Studies, Vol. 1, No. 1 (Sept) pp. 79-87.

Wotogbe, Weneka W.O. (1990). Ikwerre Indigenous Religious Beliefs and Practices. In Peuser, W. \& E. Eko (ed.) Elechi Amadi at 53: Poems, Short Stories and Papers. Pp. 80-88.

Wotogbe, Weneka W.O. (1993). Western religion versus traditional religion in Ikwerre which way Forward. Akwa an Ikwerre Socio-Cultural Journal, pp. $16-22$

Wotogbe-Weneka, W.O. (1996). Fundamentals of indigenous African religion of Ikwerre, Nigeria. A Journal of Oriental and African Studies Vol. 8 pp 143. 